\title{
EL DERECHO A LA INFORMACION EN LAS CORPORACIONES LOCALES
}

\author{
por \\ Francisco Sosa Wagner \\ Catedrático de Derecho Administrativo \\ de la Facultad de Derecho de la Universidad de León
}

Tengo noticia de dos pronunciamientos recientes del Tribunal Supremo que precisan el alcance del derecho a la información de los miembros de las Corporaciones locales en relación con los asuntos de que éstas conocen.

Sin perjuicio de precisar más adelante los términos en que se ha pronunciado el Alto Tribunal, conviene alojar el problema planteado en el más amplio del derecho a la información en las Corporaciones locales, derecho que ofrece dos vertientes a las que quiero referirme hoy aquí.

La primera se refiere al derecho de los ciudadanos a informarse de los asuntos municipales que alcanza a «obtener copias y certificaciones acreditativas de los acuerdos de las Corporaciones locales y sus actividades" y que se refiere a los ciudadanos (expresión utilizada por la Ley Básica $7 / 1985$ ) y no solamente a los vecinos, restricción ésta que intenta imponer sin adecuado rango el Reglamento de Organización, Funcionamiento y Régimen Jurídico de las Corporaciones locales (en adelante, ROF).

Si el ciudadano, además, es interesado en un procedimiento administrativo, tiene derecho a la notificación en los términos de la legislación de procedimiento común, $y$, cuando se trate de una norma de carácter general, procede su publicación. Tal ocurre 
con las Ordenanzas, los Presupuestos y las normas de los Planes urbanísticos que han de aparecer en el Boletín Oficial de la Provincia correspondiente, lo que supone, sobre todo para las Normas Urbanísticas, una rectificación importante del insuficiente sistema de publicación anterior (contenido en la Ley del Suelo y el Reglamento de Planeamiento).

Los ciudadanos pueden, además, constituir o participar en Asociaciones, a las que se permite:

Participar en los Plenos; en los Consejos sectoriales, teniendo en cuenta su especialización sectorial y su representatividad; recibir en su domicilio la convocatoria, el orden del día de los órganos colegiados y las publicaciones periódicas municipales relacionadas con su fin social; recibir subvenciones, y usar los medios públicos municipales, de acuerdo con la ordenación que hagan los Ayuntamientos.

El papel jugado por las Asociaciones de Vecinos no ha sido ni es desdeñable, pero es tal el protagonismo que el ROF les atribuye que llega incluso a olvidar a los vecinos individualmente considerados, de forma que éstos no pueden prácticamente participar, sino a través de Asociaciones, lo cual resulta ilegal, pues «las Corporaciones locales facilitarán la más amplia información sobre su actividad y la participación de todos los ciudadanos en la vida local» (art. 69.2 LB) e inconstitucional, pues el TC ha aclarado que el derecho de asociación comprende no sólo, en su forma positiva, el derecho de asociarse, sino también, en su faceta negativa, el derecho de no asociarse (Sentencia de 13 de febrero de 1981).

La segunda vertiente se refiere al derecho de los miembros de las Corporaciones locales a obtener del Presidente de la Entidad "cuantos antecedentes, datos o informaciones obren en poder de los servicios de las Corporaciones y resulten precisos para el desarrollo de su función". Esta formulación, que procede de la Ley Básica, ha sido perfilada por el ROF, a cuyo tenor la petición de acceso a las informaciones sólo podrá denegarse por resolución o acuerdo motivado, operando el silencio, con carácter positivo, por el simple transcurso del plazo de cinco días. No se precisa autorización cuando se trata de corporativos específicamente responsables de la materia cuya información se pretende, así como cuando se trate de materias que correspondan a asuntos que hayan de ser tratados en el órgano colegiado del que el peticionario 
forme parte o sea información accesible a cualquier ciudadano. Normalmente, la consulta de los expedientes o antecedentes habrá de hacerse en los archivos o dependencias municipales o provinciales.

Pues bien, todo este cuidado y matizado sistema de garantías ha intentado ser arruinado por la Resolución interpretativa de la Dirección General de Administración Local ( $B O E$ de 28 de enero de 1987), al decir que "todo ello se entiende sin perjuicio de las normas $u$ órdenes de funcionamiento interno de dichos servicios que haya podido establecer el Alcalde o Presidente como Director de la Administración de la Entidad local y jefe superior de todo su personal, o por aquellos miembros de la Corporación que ostenten delegaciones en estos ámbitos». Felizmente, el rango del instrumento donde se contiene esta excepción, que desmonta todo el sistema, no afecta al texto de la LB ni del ROF. La ilegalidad de la Resolución resulta, pues, patente.

A clarificar el panorama, sin embargo, ha contribuido el TS. Por ello debe saludarse con complacencia el contenido de su Sentencia de 9 de abril de 1987 (conociendo la apelación de un recurso fallado en Burgos). El asunto, bien simple, era el siguiente: ante la petición, denegada, de exhibición de los libros de contabilidad formulada por los vocales de una Junta vecinal, la Sala de Burgos ordena la rectificación de la conducta del Alcalde pedáneo, pues «no se trata solamente de que la legislación local reconozca el derecho de los miembros de las Corporaciones a obtener del Presidente los antecedentes o informes que obren en poder de los servicios de la Corporación, según el artículo 77 de la Ley $7 / 1985$, de 2 de abril, sino del derecho de los ciudadanos a la información sobre los asuntos locales, como consecuencia de la participación de los representantes de los vecinos, materia que está reconocida en el artículo 23 de la Constitución que, como declara la sentencia apelada, recoge el derecho de los ciudadanos a participar en los asuntos públicos, bien directamente, bien por medio de los representantes elegidos democráticamente por ellos».

El recurso, conviene saberlo, se tramitó con arreglo a la Ley de Protección Jurisdiccional de los Derechos Fundamentales, correctamente a mi juicio, pues se invocaba infracción de uno de ellos, el contenido, como hemos visto, en el artículo 23 de la Constitución española. Es por ello por lo que el asunto se tramita con inusitada rapidez: la petición inicial es de 19 de agosto de 1986, 
y la sentencia del Supremo se produce el 9 de abril de 1987. Las costas, por cierto, a la Junta vecinal empecinada en no enseñar los libros de contabilidad.

La Sentencia (también del Tribunal Supremo, de 28 de septiembre de 1987, decidiendo en apelación contra sentencia de Valladolid) contempla el problema desde otra perspectiva. La petición formulada era la de tener «en lo sucesivo acceso a cuantos antecedentes, datos e informaciones obran en poder de la Corporación, sin imponer a tal fin limitación alguna ni tampoco condición que menoscabe de forma efectiva el pleno acceso a la documentación oficial del Ayuntamiento». En este caso, el TS desestima la pretensión porque se limita a prevenir eventuales agravios futuros sin hacer ninguna petición precisa, decisión cuyo significado el propio Tribunal se encarga de perfilar al añadir que la misma no obsta a que «ante cualquier obstrucción concreta que entiendan que se hace al derecho que tienen reconocido constitucional y legalmente, puedan pedir el amparo judicial que ahora se les niega por carecer de contenido concreto".

Perfiles y matices los de estas dos sentencias que ayudan a aclarar los contornos del derecho aquí analizado. 